Volume 1, Nomor 1, Juni 2020
P-ISSN: 2722-1237, E-ISSN: 2722-2020
Website: http: pasca-umi.ac.id/index.php/jlp
This work is licensed under a Creative Commons Attribution 4.0 International License.

\title{
Pembuktian Perkara Tindak Pidana Korupsi Yang Diputus Bebas: Studi Pengadilan Negeri Makassar
}

\author{
Budiman $^{1,2}$, Hambali Thalib ${ }^{1}$, Kamri Ahmad ${ }^{1}$ \\ ${ }^{1}$ Magister Ilmu Hukum, Universitas Muslim Indonesia. \\ ${ }^{2}$ Koresponden Penulis, E-mail: budiamanwana@gmail.com
}

\begin{abstract}
ABSTRAK
Tujuan penelitan ini adalah untuk 1) untuk mengetahui pertimbangan Majelis Hakim dama penilaian sah tidaknya alat bukti dalam menjatuhkan putusan bebas terhadap tindak pidana korupsi. 2) untuk mengetahui putusan bebas terhadap yang dijatuhkan oleh Majelis Hakim dan tindak pidana korupsi sesuai dengan ketentuan hukum pidana materil dan hukum pidana formil. Penelitian ini merupakan penelitian normatif yaitu dengan mengkaji putusan besar diputuskan oleh majelis hakim di pengadilan. Hasil penelitan menunjukan bahwa pembahasan terhadap putusan bebas perkara tindak pidana korupsi Pengadilan Negri Makassar hakim dalam menjatuhkan Putusan bebas terhadap tindak pidana korupsi dengan pertimbangannya tergantung kesesuaian antara keterangan saksi dan alat bukti, serta keluarga ahli. 3) bahwa putusan bebas yang diputuskan oleh Majelis Hakim tindak pidana materil dan hukum formil.
\end{abstract}

Kata Kunci: Pembuktian; Tindak Pidana; Korupsi; Putusan Bebas

\begin{abstract}
The purpose of this research is to 1) to find out that the Judges' assessment is invalid as evidence in issuing a free decision against a criminal act of corruption. 2) to find out the verdicts free from those imposed by the Panel of Judges and corruption in accordance with the provisions of material law and formal criminal law. This research is a normative study that examines major decisions made by judges in court. The results of the research refer to the discussion of the casefree verdict in the Negri Realtor Court 3) that the acquittal is decided by the Panel of Judges for material and formal criminal acts.
\end{abstract}

Keywords: Proof; Criminal act; Corruption; Free Verdict 


\section{PENDAHULUAN}

Tindak Pidana Korupsi menurut sistem hukum pidana Indonesia diklasifikasikan menjadi Hukum Pidana Umum (ius commune) dan Hukum Pidana Khusus (iussingulareiusspeciale) (Rasul, 2009). Ketentuan-ketentuan Hukum Pidana Umum dimaksudkan berlaku secara umum seperti diatur dalam Kitab Undang-Undang Hukum Pidana (KUHP), Sedangkan ketentuan-ketentuan Hukum Pidana Khusus dimaksudkan sebagai ketentuan Hukum Pidana yang mengatur tentang kekhususan subyeknya dan perbuatan yang khusus (Gunarto, 2012)

Tindak Pidana Korupsi adalah salah satu bentuk dari Hukum Pidana Khusus di samping mempunyai spesifikasi tertentu yang berbeda dengan Hukum Pidana Umum (Dahlan, 2015). Yakni dengan adanya penyimpangan Hukum Pidana Formil atau Hukum Acara. Secara filosofis ekssitensi tindak pidana korupsi dalam Hukum Positif Indonesia sebenarnya sudah ada sejak lama (Gerungan, 2011). Yaitu sejak berlakunya Wetboek van Strafrecht voor Nederland Indie (WvS) yang pada tanggal 1 Januari 1946 resmi berlaku di Indonesia yang disebut KUHP sebagai suatu kodifikasi dan unifikasi berlaku bagi semua golongan di Indonesia sesuai dengan asas konkordonansi dan di undangkan dalam staatblad 1915 Nomor 752, tanggal 15 Oktober 1915.

Selanjutnya setelah Indonesia memproklamirkan kemerdekaan pada tanggal 17 Agustus 1945, keberadaan tindak pidana korupsi juga diatur dalam Hukum Positif Indonesia pada waktu seluruh wilayah Negara Republik Indonesia dinyatakan dalam keadaan perang berdasarkan Undang-Undang Nomor 74 tahun 1957 juncto Undang-Undang Nomor 79 tahun 1957 yang mana dalam pemberantasan tindak pidana korupsi untuk pertama kalinya dikeluarkanlah Peraturan Penguasa Militer tanggal 9 April 1957, Nomor Prt/PM/06/1957, Tanggal 27 Mei 1957 Nomor Prt/PM./03/1957, dan tanggal 1 Juli 1957 Nomor Prt/PM/011/1957,Tentang Pemberantasan Tindak Pidana Korupsi. (Ermansjah Djaja; 2010; 29).

Namun demikian untuk membuktikan bahwa telah terjadinya tindak pidana korupsi, maka diperlukan proses pembuktian,karena dalam peradilan tindak pidana korupsi, pembuktian merupakan momentum yang sangat penting, sebab dalam proses pembuktian dapat menentukan benar atau tidaknya tentang hal-hal yang didakwakan oleh Penuntut Umum (Suhendar, 2019).. Sesuai dengan asas hukum pidana bahwa setiap orang yang ditangkap, ditahan, dituntut dan/atau dihadapkan di depan sidang pengadilan wajib di anggap tidak bersalah, sebelum adanya putusan pengadilan yang menyatakan kesalahanya, dan memperoleh kekuatan hukum yang tetap (Butarbutar, 2011). Demikian Pasal 8 Undang-Undang No 48 Tahun 2009 tentang perubahan terhadap Undang Undang No 4 tahun 2004 Tentang Kekuasaan Kehakiman.

Dengan berlakunya asas presumption of Innocence ini, maka terdakwa korupsi sebelum Majelis Hakim menjatuhkan putusan, harus terlebih dahulu melalui proses pembuktian pada pengadilan tindak pidana korupsi (Mulyadi, 2015). Karena dalam proses peradilan tindak pidana korupsi, secara yuridis majelis hakim tidak boleh menjatuhkan pidana kepada seseorang kecuali dalam persidangan terbukti bahwa dakwaan Penuntut Umum didukung oleh sekurang kurangnya dua alat bukti yang sah (Mas, 2012). 


\section{3 | Journal of Lex Philosophy (JLP), Vol.1, No. 1, Juni 20200}

Diperlukan kecermatan majelis hakim dalam menilai keabsahan alat-alat bukti (keterangan saksi, keterangan ahli, surat, petunjuk, dan keterangan terdakwa) yang muncul dipersidangan serta persusaian antara alat bukti yang satu dengan yang lain,termasuk keabsahan prosedural dalam memperoleh alat-alat bukti sehingga perlu memperhatikan exclusionary rule (tidak bernilainya alat bukti yang diperoleh dengan cara ilegal, atau melanggar Hak Asasi Manusia) (Ipakit, 2015). Lebih dari itu dalam menilai keterangan saksi majelis hakim harus sungguhsungguhmemperhatikan tentang cara hidup, dan kesusilaan saksi serta segala sesuatu yang ada pada umumnya dapat mempengaruhi dapat tidaknya keterangan itu dipercaya, dalam arti pula kejelian dan objektifitasmajelis hakim diperlukan untuk menilai perlu tidaknya keterangan saksi tersebut didiskualifikasi (Wiradinata, 2016).

Bahwa pemberlakukan pembuktian dalam perkara tindak pidana korupsi, dimana Penuntut Umum harus membuktikan apa yang didakawakan kepada terdakwa, sedangkan terdakwa membuktikan bahwa apa yang didakwakan oleh Penuntut Umum tidak benar atau tidak tebukti menurut Hukum yang di ajukan selama dalam proses pembuktian,hal tersebut sesuai dengan Pasal 37 Undang-Undang Nomor 31 tahun 1999, Tentang Pemberatasan Tindak Pidana Korupsi,yang isinya bahwa terdakwa mempunyai hak untuk membuktikan bahwa ia tidak melakukan tindak pidana korupsi.

Dalam proses pemeriksaan pada pengadilan Tindak Pidana Korupsi (Thalib, Ramadhan \& Djanggih, 2017), pada acara pembutkian, majelis hakim punya kewenangan untuk menilai sah atau tidaknya alat bukti yang di ajukan olehPenuntut Umum maupun bukti bantahan yang di ajukan oleh terdakwa maka hakim menilai sah atau tidaknya alat bukti menurut hukum pembuktian(evidencelaw),yang juga akan mempengaruhi putusan majelis hakim adalah persesuaian antara alat bukti yang satu dengan yang lain (Rahman \& Qamar, 2014).

Oleh karena keterangan terdakwa tidak cukup untuk membuktikan bahwa ia bersalah melakukan tindak pidana korupsi yang didakwakan kepadanya, akan tetapi harus disertai oleh alat bukti yang lain, lebih dari itu penilaian atas kekuatan pembuktian dari suatu petunjuk (perbuataan, kejadian atau keadaan), yang diperoleh dari keterangan saksi, surat, keterangan terdakwa, harus dilakukan dengan arif dan bijaksana.

Setelah majelis hakim mengadakan pemeriksaan dengan kecermatan dan keseksamaan berdasarkan hati nuraninya, dalam ari pula Majelis Hakim harus memperhatikan bukti dalam kaitanya dengan faktor tempat, dan keadaan sekitar, dengan demikian dari bukti-bukti itu apakah dapat menguatkan dakwaan Korupsi, seperti yang didakwakan oleh Penuntut Umum yang pada akhirnya dapat ditemukan bukti-bukti yang logis dan sah, untuk dijadikan dasar pertimbangan dalam menjatuhkan putusan, sehingga dalam Vonis tersebut dihasilkan putusan yang berkualitas dan menjadi pantulan cermin tentang adanya hukum yang berasaskan keadilan.

Fungsi utama surat dakwaan dalam pemeriksaan perkara tindak pidana korupsi menjadi titik tolak landasan pemeriksaan perkara tindak pidana korupsi pada pengadilan.Atas landasan surat dakwaan inilah, ketua majelis hakim memimpin dan 
mengarahkanya jalanya seluruh pemeriksaan baik yang menyangkut pemeriksaan alat-alat bukti yang berkenanaan dengan barang bukti.

Jika penuntut umum, terdakwa atau penasihat hukum, menyimpang dari surat dakwaan, ketua majelis hakim berkewajiban sesuai dengan kewenanganya untuk meluruskan kembali kearah sesuai dengan surat dakwaan, akan tetapi, supaya ketua majelis hakim dapat menguasai jalannya pemeriksaan yang sesuai dengan surat dakwaan, harus terlebih dahulu memahami secara tepat segala sesuatu unsur-unsur konsitutif yang terkandung dalam Pasal Tindak Pidana Korupsi yang didakwakan,serta terampil mengartikan dan menafsirkan Pasal Tindak Pidana Korupsi yang didakwakan. Oleh kerana itu sebelum majelis hakim memulai pemeriksaan perkara disidangpengadilan pidana korupsi, terlebih dahulu memahami secara komprehensif semua tindak pidana korupsi yang didakwakan. Atas landasan itulah ketua majelis hakim mengarahkan jalanya pemeriksaan sehingga terhindar dari hal-hal yang berada di luar jangkauan surat dakwaan.

Di tinjau dari segi pembuktian, maka penuntut umum harus mampu membuktikan tuntutanya dalam surat dakwaan, apabila perbuatan tindak pidana korupsi yang didakwakan kepada terdakwa tidak terbukti secara sah dan meyakinkan karena tidak memenuhi asas pembuktian menurut Undang-Undang secara negatif, serta tidak memenuhi asas batas minimum pembuktian yang diatur dalam Pasal 183 KUHAP, maka terdakwa harus diputus bebas (Sriwati, 2018).

Bahwa dalam perkara tindak pidana korupsi Mahkamah Agung RI telah memutuskan sesuatu putusan penting yang menjadi patokan untuk selanjutnya yaitu diterimanya kemungkinan adanya alasan-alasan yang menghapuskan sifat dapat dihukumnya suatu perbuatan diluar KUHP, demi memenuhi tuntutankeadilan, hal ini dikemukakan oleh subyekti mantan Ketua Mahkamah Agung RI(dalam kasus Machrus Effendi), Putusan Mahkamah Agung RI No $42 \mathrm{~K}$. /Kr/1965, tanggal 8 januari 1966, dalam Putusan itu Mahkamah Agung RI memutuskan sebagai berikut;

"Suatu tindakan pada umumnya dapat hilang sifat melawan Hukum bukan hanya berdasarkan suatu ketentuan dalam perundang-undangan melainkan juga berdasarkan asas-asas Hukum yang tidak tertulis dan bersifat umum, dalam perkara ini, misalnya faktor faktor Negara tidak di rugikan, kepentingan umum di layani dan terdakwa sendiri tidak mendapat untung sehingga Mahkamah Agung RI melepaskan dari tuntutan Hukum".

Bahwa berbagai perkara tindak pidana korupsi yang diputus bebas oleh pengadilan tindak pidana korupsi dan Mahkamah Agung RI karena apa yang didakwakan oleh Penuntut Umum tidak terbukti secara sah dan meyakinkan sehingga harus dinyatakan bebas, seperti kasus Romli Atmassamita yang di vonis bebas oleh Mahkamah Agung RIdalam tingkat Kasasi,terkait dengan perkara Proyek Sistem Administrasi Badan Hukum,pada Kementerian Hukum dan Hak Asasi Manusia, dan begitu pula perkara tindak pidana korupsi dengan terdakwa Sidik Salam yang di Vonis bebas pada pengadilan tindak pidana korupsi pada Pengadilan Negeri Makassar, terkait dengan Perkara Korupsi pada Bantuan Sosial APBN tahunanggaran 2011di pengadilan tindak pidana korupsi pada Pengadilan Negeri Makassar, dan dikuatkan Oleh Mahkanah Agung RI. 
Bahwa berkaitan dengan hal tersebut ada perbedaan penafsiran terkait dengan Nilai setiap alat bukti yang di ajukan Penuntut Umum sehingga dakwaannya tidak terbukti secara sah dan menyakinkan yang mengakibatkan terdakwa di Vonis bebas oleh majelis hakim tindak pidana korupsi

\section{METODE PENELITIAN}

Tipe penelitian Hukum Normatif yaitu untuk mengakaji secara analisis terkait dengan penerapan Hukum pembuktian dakwaan perkara Tindak Pidana Korupsi yang di ajukan oleh Hakim pada Tindak Pidana Korupsi pada Pengadilan Negeri Makassar Sifat penelitian Deskriptif adalah untuk menguraikan sifat atau karakteiristik dari suatu Putusan bebas yang di putuskan oleh Majelis Hakim Pengadilan Tindak Pidana Korupsi pada Pengadilan Negri Makassar. Penedekatan penelitian studi kasus maksudnya ingin memepelajari secara komprehensif dasar dan alasan yang mendasari lahirnya putusan bebas dalam perkara Tindak Pidana Korupsi pada pengadilan Tindak Pidana Korupsi pada pengadilan negeri Makassar. Dan sebelum terbentuknya Pengadilan Tindak Pidana Korupsi. Untuk memperoleh data yang akurat dan komprehensif maka penulis memilih lokasi pada Pengadilan Tindak Pidana Korupsi pada Pengadilan Negeri Makassar. Dengan alasan sebagai berikut; Peratama Mempunyai kompentisi dalam mengadili perkara Tindak Pidana Korupsi yang terjadi di seluruh kabupaten dan kota yang ada di Propinsi Sulawesi Selatan /Sulawesi Barat. Kedua, Didukung oleh fasilitas yang sangat memadai sehingga dengan mudah dan cepat memperoleh data yang di perlukan.

\section{PEMBAHASAN}

\section{Pembuktian Perkara Tindak Pidana Korupsi Yang Diputus Bebas Di Pengadilan Negeri Makassar}

\section{Analisis Pembuktian Putusan Bebas Tindak Pidana Korupsi Nomor. 89/Pid.Sus.Tpk/2018/PN.Makassar}

Berkenaan dengan putusan bebas oleh majelis hakim sebagaimana dalam putusan Pengadilan Nomor : 89/Pid.Sus.Tpk/2018/PN.Mks, serta putusan Mahkamah Agung RI Nomor : 2703.K/Pid.Sus/2015, maka dapat saya jelaskan sebagai berikut :

Dalam putusan tingkat pertama dapat dilihat judex factie dimana terdakwah dinyatakan bebas dari segala tuntutan hukum sebagaimana dakwaan jaksa penuntut umum. Bahwa dari segi syarat formiel sebagaimana ketentuan Pasal 184 KUHP, maka surat dakwaan jaksa penuntut umum menurut penulis telah memenuhi syarat formiel tersebut. Yaitu berisi identitas terdakwah kemudian syarat tentang uraian tindak pidana yang didakwakan juga dapat dikatakan telah bersesuaian dengan syarat materielnya. Ini berarti dakwaan jaksa penuntut umum tidak dapat dibuktikan. yang menjadi persoalan adalah keharusan bagi jaksa penuntut umum membuktikan dakwaannya didepan sidang pengadilan. Karena yang yang membuktikan terlebih dahulu ialah jaksa penuntut umum itu sendiri. Upaya pembuktian inilah dituntut kemampuan untuk menyelesaikan antara apa yang didakwakan dengan alat-alat yang dan barang bukti yang demikian. 
Dalam faktanya persidangan terdapat lebih dari seratus bukti surat yang diajukan oleh jaksa penuntut, beberapa saksi termasuk saksi a de charge (saksi yang meringankan terdakwa) dan juga saksi ahli.

Berdasarkan alat bukti tersebut, maka majelis hakim maupun penasehat hukum mencoba menghubungksn dngan realitas proyek Yayasan Masjid Kota Polopo yang sumber dananya berasal dari dana hibah pemerintah setempat tahun anggaran 20082009 sebesar Rp1.505.255.650 (seratus milliars lima ratus lima juga dua ratus lima puluh lima ribu enam ratus lima puluh).

Menurut analisis keuangan yang diajukan oleh Jaksa penuntut, bahwa dalam proyek itu terdakwa merugikan Keuangan Negara sebesar Rp 306.584.722,44 (tiga ratus enam juta lima ratus delapan puluh empat ribu tujuh puluh dua empat puluh empat rupiah). Terdapat beberapa alasan yuduris maupun empiris sehingga jaksa penuntut umum menyebut jerugian Negara tersebut berdasarkan analisis keuangan dari BPKP. Alasanalasan yudiris jaksa penuntut menyebut kerugian itu antara lain :

1. Proyek tersebut tidak dilakukan melalui proses tender sebagaimana ketentuan yang berlaku,sebagaimana diatur di undang-undang misalnya Kepres Nomor:8o tahun 2003 tentang pengadaan barang dan jasa, khususnya pasal 10 ayat (1) dan pasal 17. Kemudian ada juga Undang-undang 18 tahun 1999 tentangjasa kontruksi. Undang-undang ini mengatur tentang syarat mitra kerja yang akan melaksanakan proyek yang di tenderkan tersebut. Misalnya harus bersertifikat, kemudian harus berbadab usaha.

2. Alasan berikut ditemukan adanya ketidaksesuaian antar volume pekerjaan yang dilaksanakan oleh pelaksanaan proyek dengan hasil pemeriksaan fisik Tim Ahli Kontruksi ata pelaksanaan renovasi proyek yang dimaksud. Demikian antara lain alasan jaksa penuntut umum. Tentunya masih ada alasan-alasan lainnya sebagaimana yang sudah dikemukakan pada data penelitian ini.

Jaksa Penuntut umum pun menguraikan unsur-unsur yang terdapat dalam pasal-pasal yang didakwakan yang meliputi pasal 2 ayat (1) dan pasal 3 undang-undang Nomor: 31/1999 Jo. No.20 Tahun 2001 tentang Pemberantasan Tindak Pidana Korupsi. Pasalpasal tersebut dijuntokan dengan pasal 5 ayat (1) KUHP.

Pasal 2 ayat (1) ada dua bagian isinya. Namun menurut jaksa penuntut umum hanya bagian yang pertama saja, yakni dilakukan oleh seorang, dengan cara melawan hukum, dengan masud memperkaya diri sendiri atau orang lain, atau suatu korporas, yang merugikan keuangan Negara atau perekonomian Negara.

Alasan jaksa penuntut umum adalah bahwa dalam faktanya, terdakwa melakukan menjalankan proyek sebagaimana perkara a quo ada dua beberapa ketidak seseuaian. Dan ketidaksesuaian itulah yang dipandang oleh jaksa Penuntut Umum sebagai pelanggaran yang berakibat terjadinya korupsi.

Antara lain pelanggaran yang dimaksud ialah tidak ada proses tender. Fakta dalam pelaksanaan proyek dalam perkara a quo dinyatakan perbuatan melanggar hukum karena tidak dilakukan proses lelang/tender yang harus diumumkan sebagaimana diatur dalam Kepres Nomor: 8o/2003 tentang pengadaan Barang dan jasa, kemudian Undang-undang Nomor: 18 Tahun 1999 Tentang Jaksa Kontruksi.

Berdasarkan ketentuan pasal 10 ayat (1) Kepres No.80/2003 ditegaskan bahwa bila mana proyek tersebut bernilai Rp 50 juta keatas, maka harus dilakukan proses lelang untuk tender melalui suatu panitia lelang. Sedangkan terdakwa tidak melalkukan 


\section{7 | Journal of Lex Philosophy (JLP), Vol.1, No. 1, Juni 20200}

proses lelang tersebut berdasarkan ketentuan diatas. Padahal nilai proyek diatas Rp 1 milyar. itu berarti terjadi kesalahan. Perseolannya adalan apakah kesalah ini sengaja atau tidak untuk menilai ini sangat menentukan proses pembuktian di persidangan.

Menurut dalam Surat Dakwaan Jaksa Penuntun, terdakwa melakukan suatu kesalahan dalam pemborongan proyek karna diberikan kepada pemborong yang tidak memiliki kualifikasi tender contoh misalnya, harus memiliki sertifikat keahlian kerja (SKK) sebagaimana diatur dalam pasal 9 ayat(2) dan pasal 11 ayat (1) UU No. 18/1999 tentang jasa kontruksi meskipun demikian, menurut hemat penulis konteks ini adalah kontek persyaratan administrasi bagi setiap peserta lelang jika sekiranya suatu proyek itu hendak ditenderkan. Berarti jika terjadi pelanggaran mengenai ketentuan pasal tersebut dalam konteks ini maka itu dinamakan pelanggaran administrasi oleh karena ituperli dapat dipastikan adanya pelanggaran pidana. Jika demikian kemana harus dimintakan pertanggung jawaban atas perbuatan demikian?.

Berkenaan dengan kewajiban lelang suatu priyek yang nilainya Rp 50 juta keatas dapa dilihat ketentuannya sebagai berikut:

1. Pasal 10 ayat (1) Kepres No.8o Tahun 2003 tentang pedoman pelaksanaan barang dan jasa / pemerintah : "panitia pengadaan wajib dibentuk untuk semua pengadaan dengan nilai diatas Rp 50 juta ruoiah.

2. Pasal 17 Kepres No 8o. Tahun 2003 tentang pedoman pelaksanaan barang dan jasa / pemerintah : metode pemilihan penyedia barang/jasa pemborongan/jasa lainnya.

Ketentuan-ketentuan tersebut pada tingkat pertama juga tidak dilakukan oleh terdakwa. Yang menjadi pertanyaan apakah pelanggaran semacam ini bisa berimpilikasi dalam hal tinda pidana korupsi, dalam tataran ini bisa kita bandingkan antara uraian jaksa penuntut umu tentang unsur-unsur tindak pidana yang didakwakan dengan hasil pembuktiaan sidang dipengadilan, kemudian masuk pada pertimbangan hukum hakim berikut keterangan saksi ahli yang diajukan oleh terdakwa.

Menurut ursisn jaksa penuntut umum sekedar bertalian dengan unsur-unsur tindak pidana yang didakwakan seperti pasal 2 ayat (1) dan pasal 3 UU No. 31 tahun 1999 sebagaimana diubah dengan UU No.20/21 tentang pemberantasan tindak pidana korupsi pada dasarnya sudah memenuhi kualifikasi tentang unsur-unsur tersebut. Akan tetapi ada satu hal yang penulis lihat bahwa keterangan saksi ahli yang diajukan oleh terdakwa, cenderung kepada pelanggaran administrasi. Sehingga ada kesan bahwa sekalipun ada kesalahan administrasi tetapi. Menurut hemat penulis Pasal 1 ayat (2) dan pasal 11 ayat (1) UU No. 18/1999 kontruksi hukum tidak menjadi pertimbangan Hakim Pengadilan terutama yang berkaitan dengan pasal 11 ayat (1) UU No.18/1999 dan diubah dengan UU No.20 Tahun 2001.

Pasal 11 ayat (1) berbunyi sebagai berikut :

"Badan usaha sebagai mana dimaksud pada pasal 8 dan orang per orangan sebagai mana dimaksud dalam pasal 9 harus bertanggung jawab terhadap hasil pekerjaan."

Atas dasar itu semua, maka penulis berfikir bahwa jika mengacu pada ketentuan perundang-undangan tersebut maka sudah dapat diprediksi bahwa terdakwa pastilah dinyatakan bersalah. Akan tetapi dalam perkara a quo mulai dari tingkat pertama kemudian dilakukan kasasi oleh jaksa penuntut umum, justru hasilnya berbanding 
terbalik, yaitu terdakwa dibebaskan. Bagiamana gerangan majelis hakim menilai bahwa terdakwa tidak terbukti bersalah melakukan perbuatan tindak pidana korupsi sebagaimana didakwakan oleh jaksa penuntut umum.

Pertama istilah yang diuraikan dalam putusan yang menjadi sorotan ialah istilah 'Merugikan' keuangan Negara, bisa bermakna uang Negara rugi karenanya dan atau uang Negara berkurang karnanya. Lalu uang yang digunakandapan pembangunan proyek berasal dari dana Hibah yang tertaung didalam RAB. Jadi penilaian Jaksa Penuntut Umum, uang yang digunakan bersal dari keuangangan Negara.

Kedua, terdapat juga dalam pertimbangan hukum hakim yang menyebutkan sebagaimana dalam fakta persidangan bahwa, baik keterangan terdakwa maupun keterangan saksi P,dan saksi Ir. M menyatakan bahwa " Terdakwa tidak pernah menerima uang dari renovasi Masjid Agung Palopo. Justru pengalihan yang tidak sesuai RAB tersebut untuk membangun beberapa item seperti dalam bukti T.15”.

Menanggapi menurut hemat penulis keterangan penulis sangat kuat karena dikemukakan oleh tiga orang saksi didepan sidang pengadilan, alasannya bahwa uang tersebut adalah uang pembiyaan RAB yang dialihkan dan juga digunakan untuk merenovasi bagian taman,bagian kaligrafi dan lain lain. Semua pengalihan pembangunan atau renovasi masjid raya palopo tersebut menjadi sangat bermanfaat bagi masyarakat umum dan bahkan sudah dinikmati oleh masyarakat tersebut, sehingga jika dikatakn merugikan keuangan Negara tentulah tidak demikian inilah salah satu pokok pertimbangan hakim yang menjadi dasar dan menyatakan bahwa "unsur yang merugikan keuangan Negara atau perekonomian Negara tidak terbukti oleh perbuatan dakwa".

Dengan demikiaan dalam mengacu pada system pemidanaan tentang unsur-unsur tindak pidana, bilamana ada satu unsur yang tidak terbukti dari sekian unsur yang tindak pidana yang didakwakan, maka seyobyanya memang terdakwa harus bebas dari dakwaan jaksa penuntut umum.

Adapun putusan MA No. 2703/K/Pid.Sus.2015 dimana dalam perkara ini yang dikenal dengan perkara sabrir pada pengadilan tingkat pertama terdakwa dinyatakan bebas akan tetapi pada tingkat kasasi dimohonkan jaksa penuntut umu dinyatakan terdakwa bersalah.

Secara sepintas kita dapat melihat pertimbangan majelis hakim tingkat pertama yang memutus bebaskan kepada terdakwa, antara lain pertimbangang-pertimbangan tersebut adalah:

1. Menyatakan terdakwa MS.Sag.MSi tidak terbukti secara sah dan menyakinkan bersalah melakukan tindak pidana korupsi sebagai mana yang didakwakan dalam dakwaan primair dan subsidair.

2. Membebaskan terdakwa oleh karena itu dari dakwaan primair dan subsidair dakwaan penuntut umum.

3. Memerintahkan terdakwa dibebaskan dari tahanan secara setelah putusan di ucapkan.

4. Memulihkan hak-hak terdakwa dalam kemampuan, kedudukan, dan harkat dan martabatnya.

5. Menetapkan barang-barang buktu ( 1 -19) dikembalikan kepada penuntut umum untuk dijadikan barang bukti dalam perkara yang lain. 
Berdasarkan putusan pengadilan tingkat pertama tersebut perkara no. 17/Pid.Sus/Tpk/2015/PN. Mks jaksa penuntut umu melakukan upaya hukum kasasi dengan akta permohonan Kasasi nomor 25 akta pid.sus/tpk/2015/PN.Mks.

Hal yang menarik dalam perkara kasasi yang diajukan oleh JPU ialah Mahkamah Agung mengacu kepada Putusan Mahkamah Konsitusi Nomor 114/PUU-X/2012 tanggal 28 maret 2013 yang menyatakan bahwa "frasa kecuali terhadap putusan bebas" dalam pasal 244 KHUAP tersebut tidak mempunyai kekuatan hukum yang mengikat, maka mahkamah agung berwenang memriksa permohonan kasasi terhadap putusan bebas. Maka dari itu mahkamah agung dalam putusannya dalam perkara No 17/Pid.Sus/Tpk/2015/PN.Mks memeriksa sendiri dan memberikan dan pertimbangan pertimbangan seabagai berikut :

Bahwa Judex Factie Majelis Hakim Tingkat Pertama tidak menerapkan peraturan hukum ataau menerapkan peraturan hukum tidak sebagaimana semestinya Pasal 253 ayat (1) sub a KHUAP yang dalam hal ini , bahwa judex faxtice dalam perimbangannya menyangkut unsur yang dengan tujuan menguntungkan diri sendiri atau suatu porkorasi tidak terpenhuni sebagaimana pertimbangan majelis hakim tersebut. Menimbang bersadarkan fakta hukum diatas bahwa terdakwa tidak pernah mengajukan proposal dan menerima cek serta tanda tangan tangan terdakwa dalam ketiga cek tersebut adalah tanda tangan karanga general desaign berdasarkan hasil laporan pengajuan korensif ( sticlly confideranld) bahwa judex factie telah mempertimbangkan pengajuan suatu alat bukti dengan tidak menerapkan hukum atau tidak sebagaimana mestinya. Sesuai ketentuan yang dipersyaratkan berdasarkan Pasal 28 ayat (1) UU. No. 46.2009 tentang Pengadilan tindak pidana korupsi.

Bahwa judex factie tidak menguji atau meneliti tentang tata cara prosedur perolehan dari alat bukti surat yang diajukan oleh terdakwa di persidangan emudian daripada itu, Mahkamah Agung RI mwngadili dan mengabulkan permohonan kasasi jaksa penuntut umum tersebut. Membatalkan Putusan pengadilan Tipikor tingkat pertaman Nomor 17/Pid.Sus/Tpk/2015/PN.Mks tanggal 12 agustus 2015.

Menimbang, sebelum Majelis Hakim mempertimbangkan terbukti tidaknya Terdakwa melakukan tindak pidana yang didakwakan, Majelis Hakim terlebih dahulu akan mempertimbangkan keabsahan alat bukti yang diajukan baik oleh Penuntut Umum maupun oleh Terdakwa melalui Penasihat Hukum Terdakwa berdasarkan amanah ketentuan Pasal 28 UU No. 46 Tahun 2009 tentang Pengadilan Tindak Pidana Korupsi yang berbunyi:

1) Semua alat bukti yang diajukan di dalam persidangan, termasuk alat bukti hasil penyadapan, harus diperoleh secara sah berdasarkan ketentuan peraturan perundangan- undangan;

2) Hakim menentukan sah tidaknya alat bukti yang diajukan di muka persidangan baik yang diajukan oleh Penuntut Umum maupun oleh terdakwa.

Menimbang, semua Saksi yang diajukan oleh Penuntut Umum di persidangan sebelum memberikan keterangan telah bersumpah akan memberikan keterangan yang benar tidak lain daripada yang sebenarnya dan pada pemeriksaan tahap penyidikan maupun di persidangan, tidak dibawah tekanan baik fisik maupun psikis, dengan demikian alat bukti keterangan saksi sah dan keterangannya dapat menjadi dasar pertimbangan hukum dalam putusan ini ; 
Menimbang, tentang alat bukti surat yang diajukan oleh Penuntut Umum, oleh karena cara perolehannya sudah sesuai dengan ketentuan Hukum Acara Pidana, maka dapat dijadikan sebagai alat bukti yang sah dalam perkara ini.

Menimbang, Terdakwa dalam memberikan keterangan baik pada pemeriksaan tingkat penyidikan maupun di depan persidangan telah dilakukan secara bebas dan tanpa tekanan, maka keterangan Terdakwa sah sebagai alat bukti, oleh karenanya dapat menjadi dasar pertimbangan dalam putusan;

Menimbang, bukti surat yang diajukan oleh Penasihat Hukum Terdakwa, karena tidak ditemukan adanya bukti yang membuktikan sebaliknya bahwa bukti tersebut diperoleh secara tidak sah, maka merupakan alat bukti yang sah dan dapat dijadikan sebagai alat bukti dalam putusan ini.

Pembelaan Penasihat Hukum Terdakwa tidak beralasan, oleh karenanya harus dikesampingkan; Menimbang, berdasarkan alat bukti dan barang bukti yang diajukan diperoleh fakta-fakta hukum sebagai berikut:

Pada TA. 2008 Pemerintah Propinsi Sulawesi Selatan Sulawesi Selatan menganggarkan dalam APBD TA. 2008 belanja bantuan sosial seluruhnya sebesar Rp. 151.476.442.80o,oo.- ( seratus lima puluh satu milyar empat ratus tujuh puluh enam juta empat ratus empat puluh dua ribu rupiah) yang terdiri dari Bantuan sosial Organisasi kemasyarakatan sebesar Rp 149.976.442.80o,oo.- ( seratus empat puluh milyar sembilan ratus tujuh puluh enam juta empat ratus empat puluh dua ribu delapan ratus rupiah) dan belanja bantuan partai Politik sebesar Rp. 1.500.000.000,o0.-. (satu milyar lima ratus juta rupiah) Belanja bantuan sosial tersebut dianggarkan pada Sekretariat Daerah dan penatausahaannya dilakukan pada Biro Keuangan dan Biro kesejahteraan Agama dan Pemberdayaan Perempuan (Biro KAPP).

- Mekanisme pemberian bantuan sosial Tahun Anggaran 2008 tanpa ada peraturan dari gubernur selaku Kepala Daerah Sulawesi Selatan yang mengatur tentang tata cara pemberian bantuan dan pertanggungjawabannya. Saksi H. Andi Muallim, S.H. M.Si selaku Sekretaris Daerah Propinsi Sulawesi Selatan melaksanakan pemberian bantuan sosial Tahun 2008 dengan mekanisme sebagai berikut :

- Pihak organisasi kemasyarakatan mengajukan surat permohonan bantuan dengan dilampiri dengan proposal kegiatan ditujukan kepada Gubernur Propinsi Sulawesi Selatan, kemudian setelah itu saksi H. Andi Muallim, S.H. M.Si selaku Sekretaris Daerah Propinsi Sulawesi Selatan melakukan verifikasi proposal permohonan bantuan sosial tersebut dan kemudian menerbitkan disposisi berupa saran dan pertimbangan baik kepada Kepala Biro Keuangan yaitu Saksi Drs. H. Muh. Yushar Huduri, maupun kepada Biro KAPP atas nama Drs.H.A.Sumange Alam, M.Si, kemudian digantikan oleh A. Ilham Gazaling berdasarkan sifat kegiatan dan besaran permohonan bantuan sosial yang tercantum dalam permohonan yang dimaksud.

- Surat permohonan bantuan dengan lampiran proposal kegiatan tersebut dilakukan verifikasi kembali oleh Kepala Biro Keuangan Saksi Drs. H. Muh. Yushar Huduri dan Kepala Biro KAPP atas nama Drs.H.A.Sumange Alam, M.Si yang kemudian digantikan oleh A. Ilham Gazaling Setalah dilakukan verifikasi dan kemudian menerbitkan nota pertimbangan/nota dinas dari Kepala Biro Keuangan dan Kepala Biro KAPP, adapun verifikasi yang dilakukan hanya terhadap 
ketersediaan/kemampuan anggaran/ dana yang tersedia baik di Biro Keuangan maupun di Biro KAPP tanpa melakukan pengujian kebenaran material surat-surat bukti atas tagihan sebelum memerintahkan pembayaran;

Menimbang, selanjutnya Majelis Hakim akan mempertimbangkan apakah berdasarkan fakta-fakta hukum yang terungkap di persidangan tersebut, Terdakwa dapat dinyatakan telah terbukti secara sah dan meyakinkan melakukan tindak pidana yang didakwakan kepadanya;

Menimbang, Terdakwa telah didakwa oleh Penuntut Umum dengan dakwaan subsideritas atau primer subsider, maka Majelis Hakim terlebih dahulu mempertimbangkan dakwaan primer, jika dakwaan primer terbukti, maka dakwaan subsider tidak dipertimbangkan lagi, akan tetapi jika dakwaan primer tidak terbukti, maka dakwaan subsider harus dipertimbangkan;

Menimbang, Terdakwa pada dakwaan primer didakwa melakukan tindak pidana sebagaimana diatur dan diancam pidana dalam Pasal 2 ayat (1) Jo. Pasal 18 ayat (1) huruf a, b, d, ayat (2) dan ayat (3) Undang-undang RI Nomor 31 Tahun 1999 Tentang Pemberantasan Tindak Pidana Korupsi sebagaimana telah diubah dengan Undang-undang RI Nomor 20 Tahun 2001

Tentang Perubahan Atas Undang-undang RI Nomor 31 Tahun 1999 Tentang Pemberantasan Tindak Pidana Korupsi Jo. Pasal 55 ayat (1) ke-1 KUHP Jo. Pasal 64 ayat (1) KUHP;

Menimbang, oleh karena pada dakwaan primer Pasal 2 ayat (1) Undang-undang RI Nomor 31 Tahun 1999 Tentang Pemberantasan Tindak Pidana Korupsi sebagaimana telah diubah dengan Undang-undang RI Nomor 20 Tahun 2001 Tentang Perubahan Atas Undang-undang RI Nomor 31 Tahun 1999 Tentang Pemberantasan Tindak Pidana Korupsi dijunctokan dengan Pasal 18 ayat (1) huruf a, b, d ayat (2) dan ayat (3) Undang-undang RI Nomor 31 Tahun 1999 Tentang Pemberantasan Tindak Pidana Korupsi sebagaimana telah diubah dengan Undang-undang RI Nomor 20 Tahun 2001

Tentang Perubahan Atas dan Pasal 55 ayat (1) ke-1 KUHP serta Pasal Pasal 64 ayat (1) KUHP, maka masing-masing akan dipertimbangkan tersendiri dan yang pertama-tama akan dipertimbangakan adalah Pasal 2 ayat (1) Undangundang RI Nomor 31 Tahun 1999 Tentang Pemberantasan Tindak Pidana Korupsi sebagaimana telah diubah dengan Undang-undang RI Nomor 20 Tahun 2001 Tentang Perubahan Atas Undang-undang RI Nomor

31 Tahun 1999 Tentang Pemberantasan Tindak Pidana Korupsi, yang unsur- unsurnya adalah sebagai berikut:

1. Unsur Melawan Hukum

Menimbang, Undang-undang Nomor 31 tahun 1999 tentang pemberantasan tindak pidana korupsi sebagaimana telah diubah dengan Undang-undang Nomor 20 tahun 2001 menentukan bahwa pengertian"secara melawan hukum" adalah dalam pengertian formil maupun materii. Hal mana jelas dinyatakan dalam penjelasan umum UndangUndang tersebut yang dikutip berbunyi sebagai berikut " agar dapat menjangkau berbagai modus operandi penyimpangan keuangan negara atau perekonomian Negara 
yang semakin canggih dan rumit maka tindak pidana yang diatur dalam UndangUndang ini dirumuskan sedemikian rupa sehingga meliputi perbuatan-perbuatan memperkaya diri sendiri atau orang lain atau suatu "koorporasi" secara melawan hukum dalam pengertian formil dan materiil sedangkan penjelasan pasal 2 ayat (1) menyatakan bahwa yang dimaksud secara "melawan hukum" dalam pasal ini mencakup perbuatan melawan hukum dalam arti formil maupun dalam arti materiil, yakni meskipun perbuatan tersebut tidak diatur dalam peraturan perundangundangan namun apabila perbuatan tersebut dianggap tercela karena tidak sesuai dengan rasa keadilan atau norma-norma kehidupan sosial dalam masyarakat maka perbuatan tersebut dapat dipidana,

Menimbang,"wederrechtelijk" tidak diartikan secara formil saja,akan tetapi meliputi pengertian "materiele wederrechtelijk" yaitu suatu perbuatan yang mencakup ketidaksesuaian dengan nilai-nilai yang hidup dalam masyarakat, tegasnya suatu perbuatan yang dipandang tercela oleh masyarakat atau rasa keadilan masyarakat terusik (vide.MARI putusan No.275.K.Pid/1983 tanggal 29 Desember 1993);

Menimbang, dalam ilmu hukum pidana dikenal dua fungsi dari ajaran sifat melawan hukum yang materiil yaitu ajaran sifat melawan materiil dalam fungsinya yang positif dan ajaran sifat melawan hukum materil dalam fungsinya yang negatif.

Menimbang, tentang makna melawan hukum secara materil sebagaimana penjelasan Pasal 2 Undang-undang Nomor 31 Tahun 1999 tentang Pemberantasan Tindak Pidana Korupsi yang telah diubah dan ditambah dengan Undang-undang Nomor 20 Tahun 2001 tentang Perubahan Undang-undang Nomor 31 Tahun 1999 tentang Pemberantasan Tindak Pidana Korupsi telah dibatalkan oleh Putusan Mahkamah Konstitusi Nomor : 003/PUU-IV/2006 tanggal 25 Juli 2006 yang menyatakan penjelasan Pasal Undang-undang Nomor 31 Tahun 1999 jo Undang-Undang Nomor: 20 Tahun 2001 dinyatakan telah bertentangan dengan Undang-Undang Dasar Republik Indonesia Tahun 1945 dan telah dinyatakan tidak mempunyai kekuatan hukum mengikat, dengan demikian melawan hukum secara materil pasca Putusan Mahkamah Konstitusi tidak lagi menjadi alasan untuk penjatuhan pidana, tetapi menjadi alasan peniadaan pidana di luar undang-undang.

Menimbang, tentang pengertian melawan hukum dalam hukum pidana dikenal pengertian "melawan hukum" (wederrechtelijk) seperti bertentangan dengan hukum, bertentangan dengan hak orang lain, tanpa hak sendiri. Dalam konteks ketentuan Pasal 2 Undang-undang Nomor 31 Tahun 1999 Tentang Pemberantasan Tindak pidana Korupsi sebagaimana telah diubah dan ditambah dengan Undang-undang Nomor 20 Tahun 2001 tentang Perubahan Undang-Undang Nomor 31 Tahun 1999 tentang Pemberantasan Tindak Pidana Korupsi, Prof DR (Jur.) Andi Hamzah dalam bukunya Pemberantasan Korupsi Melalui Hukum Pidana Nasional dan Internasional Penerbit PT Raja Grafindo Persada, Jakarta. 2005 halaman 129 berpendapat "Dalam delik korupsi, terutama Pasal 2 UU PTKP 1999, "paling tepat dipakai pengertian "melawan hukum "sebagai" tidak mempunyai hak sendiri untuk menikmati keuntungan (korupsi) tersebut”.

Menimbang, tentang unsur ini Penuntut Umum dalam tuntutan pidana tidak secara khusus mengkaji dan menganalisis untus ini, akan tetapi menialai dari sisi subyek 
pelaku tindak pidana dan dari perspektif subyek pelaku tindak pidana dalam tuntutan pidana Penuntut Umum halaman 39-42 berpendapat tidak terpenuhi, demikian pula Tim Penasihat Hukum Terdakwa Halaman 75 dari 88 Putusan Nomor.17/Pid. Sus. TPK/2015/PN. Mks dalam pembelaan pada halaman 37-39 pada prinsipnya sependapt tuntutan

Penuntut Umum;

Menimbang, meskipun Penuntut Umum dan Penasihat Hukum Terdakwa pada prinsipnya sependapat bahwa Terdakwa tidak terbukti secara sah dan meyakinkan melakukan tindak pidana pada dakwaan primer, namun Majelis Hakim tidak serta merta sependapat dengan Tuntutan Penuntut Umum dan Pembelaan Penasihat Hukum Terdakwa mengenai terbukti tidaknya Terdakwa melakukan tindak pidana pada dakwaan primer, oleh karenanya Majelis Hakim tetap harus mempertimbangkan terpenuhi tidaknya

berdasarkan fakta hukum yang terungkap di persidangan, antara lain sebagai berikut:

- Pada Tahun 2008 Terdakwa menduduki posisi sebagai Kepala Sekretariat Partai Demokrasi Kebangsaan Kota Makassar;

- Terdakwa tidak memiliki dan juga bukan pengurus Lembaga/LSM atau Yayasan, Terdakwa pada Tahun 2008 hanya menduduki posisi sebagai Kepala Sekretariat Partai Demokrasi Kebangsaan Kota Makassar dan juga aktif di KNPI serta aktif sebagai Mahasiswa Program Strata 2 di Universitas Hasanuddin;

- Terdakwa tidak pernah mengajukan Proposal untuk mendapatkan dana Bantuan Sosial pada Tahun 2008, Terdakwa juga tidak pernah datang ke Kantor Gubernur Propinsi Sulawesi Selatan baik untuk memasukkan proposal untuk mendapatkan Dana Bantuan Sosial serta Terdakwa tidak pernah menerima cek baik dari Saksi Hj. Nurlina, Saksi Anwar Beddu maupun dari Ratno Tajuddin;

- Tanda tangan Terdakwa dalam cek masing-masing sebagai berikut:

1. 1 (satu) lembar cek No. CB.oo7959 uang sejumlah rupiah seratus juta saja Rp10o.0oo.ooo,- yang dikeluarkan oleh PT. Bank Pembangunan Daerah Sulawesi Selatan tertanggal 27 Mar 2008;

2. 1 (satu) lembar cek No. CB. o11499 uang sejumlah rupiah dua ratus juta saja Rp200.00o.ooo,- yang dikeluarkan oleh PT. Bank Pembangunan Daerah Sulawesi Selatan tertanggal 23 Apr 2008;

3. 1 (satu) lembar cek No. CB. 06908 o uang sejumlah rupiah dua ratus tiga puluh juta saja Rp230.00o.ooo,- yang dikeluarkan oleh PT. Bank Pembangunan Daerah Sulawesi Selatan tertanggal o1 Sep 2008; adalah tanda tangan karangan atau Spurius Signature karena mempunyai bentuk umum (general design) berbeda dengan tanda tangan Mustagfir Sabry, S.Ag, M.Si alias Mustagfir Alias Mustagfir Sabri Alias Mustagfir Sabri Alkhair Alias Mustagfir Sabri Alkhair;

Menimbang, fakta hukum bahwa Terdakwa tidak pernah mengajukan proposal, tidak pernah menerima cek di kantor Gubernur serta Tanda tangan Terdakwa dalam cek masing-masing sebagai berikut:

- 1 (satu) lembar cek No. CB.oo7959 uang sejumlah rupiah seratus juta saja Rpıo.ooo.ooo,- yang dikeluarkan oleh PT. Bank Pembangunan Daerah Sulawesi Selatan tertanggal 27 Mar 2008; 
- 1 (satu) lembar cek No. CB. o11499 uang sejumlah rupiah dua ratus juta saja Rp20o.ooo.ooo,- yang dikeluarkan oleh PT. Bank Pembangunan Daerah Sulawesi Selatan tertanggal 23 Apr 2008;

- 1 (satu) lembar cek No. CB. o69o8o uang sejumlah rupiah dua ratus tiga puluh juta saja Rp230.00o.ooo,- yang dikeluarkan oleh PT. Bank Pembangunan Daerah Sulawesi Selatan tertanggal o1 Sep 2008;

Tangan karangan atau Spurius Signature karena mempunyai bentuk umum (general design) berbeda dengan tanda tangan Mustagfir Sabry, S.Ag, M.Si merupakan indikator bahwa Terdakwa tidak melakukan perbuatan yang dapat dikualifikasi sebagai perbuatan melawan hukum dalam konteks unsur ini karena tidak pernah menerima pencairan dana Bantuan Sosial pada Tahun 2008, meskipun berdasarkan keterangan Saksi Hj. Noerhayati Amirullah yang menerangkan pada pokoknya bahwa setelah Saksi mendapat informasi dari Adil Patu untuk mengajukan proposal, maka Saksi memerintahkan Kepala Sekolah Madrasah Tsanawiyah Al-Hidayah untuk membuat proposal RKB dan setelah selesai, Saksi menyampaikan kepada Adil Patu kalau proposal sudah selesai, maka diperintahkan Adil Patu untuk menyampaikan kepada Terdakwa, akan tetapi Saksi tidak menyaksikan penyerahan proposal kepada Terakwa, sedangkan keterangan Saksi Arqam Abdulrahman yang menerangkan pada pokoknya bahwa setelah proposal selesai ada yang menjemput, tetapi bukan Terdakwa, namun setelah Saksi tanyakan kepada orang tersebut dijawab disuruh oleh Terdakwa;

Menimbang, meskipun keterangan kedua Saksi tersebut demikian dan jika seandainya Terdakwa telah menerima proposal dari Madrasah Tsanawiyah Al-Hidayah, namun tidak terungkap fakta yang dapat membuktikan bahwa Terdakwa atau ada orang lain yang disuruh oleh Terdakwa untuk memasukkan proposal tersebut ke kantor Gubernur untuk mendapatkan dana Bantuan Sosial Pada Tahun 2008, serta menerima cekselanjutnya mencairkan cek tersebut, meskipun Saksi Andi Tuty Zurianty, SE Binti Andi Hambali yang menjabat sebagai Teller menjelaskan bahwa yang membawa dan mencairkan cek harus melampirkan foto copy KTP, menandatangani pada bagian belakang cek sebanyak 2 (dua) kali yaitu pertama sebelum pencairan dan kedua setelah pencairan serta menulis nama dan alamat serta nomor telepon, namun Saksi tidak melihat dan tidak dapat memastikan bahwa Terdakwa menandatangani tiga lembar cek tersebut pada bagian belakang, sedangkan Nama Terdakwa tercantum dalam Rekening

Koran berdasarkan keterangan Saksi Hj. Fauziah dan Saksi Andi Tuty Zurianty, SE Binti Andi Hambali menerangkan bahwa nama yang tercantum dan termuat dalam rekening Koran adalah berdasarkan nama tertera dan tertulis pada bagian belakang cek;

Menimbang, Terhadap keterangan Saksi-Saksi tersebut tidak dapat melumpuhkan alat bukti berupa Berita Acara Pemeriksaan Laboratoris Kriminalistik dari Pusat Laboratorium Forensik Laboratorium Forensik Cabang Makassar No. LAB : 1654/DTF/VII/2015 tanggal 27 Juli 2005;

Menimbang, berdasarkan pertimbangan di atas unsur ini tidak terpenuhi; Menimbang, oleh karena salah satu bagian inti delik (bestandelen delik) Pasal yang didakwakan 
pada dakwaan primer tidak terpenuhi maka, terdakwa tidak terbukti secara sah dan meyakinkan bersalah melakukan tindak pidana pada dakwaan primer, dengan demikian terdakwa harus dibebaskan dari dakwaan primer tersebut;

Menimbang, Selanjutnya Majelis Hakim akan mempertimbangkan dakwaan subsider;

Menimbang, Terdakwa pada dakwaan subsider didakwa melakukantindak pidana sebagaimana diatur dan diancam pidana pada Pasal 3 Jo. Pasal 18 ayat (1) huruf a, b, d, ayat (2) dan ayat (3) Undang-undang No. 31 Tahun 1999 tentang Pemberantasan Tindak Pidana Korupsi sebagaimana telah diubah dengan Undang-undang RI Nomor 20 Tahun 2001 tentang Perubahan atas Undang-undang Nomor 31 Tahun 1999 tentang Pemberantasan Tindak Pidana Korupsi Jo. Pasal 55 ayat (1) ke-1 KUHP Jo. Pasal 64 ayat (1) KUHP;

Menimbang, oleh karena dakwaan Subsidair Pasal 3 Undangundang Nomor 31 Tahun 1999 tentang Pemberantasan Tindak Pidana Korupsi sebagaimana telah diubah dengan Undang-undang Nomor 20 Tahun 2001 tentang Perubahan Atas Undang-undang Nomor 31 Tahun 1999 tentang Pemberantasan Tindak Pidana Korupsi di junctokan dengan Pasal 18 ayat (1) huruf a, b, d, ayat (2) dan ayat (3) Undang-undang Nomor 31

Tahun 1999 tentang Pemberantasan Tindak Pidana Korupsi sebagaimana telah diubah dengan Undang-undang Nomor 20 Tahun 2001 tentang perubahan Undang-undang Nomor 31 Tahun 1999 tentang Pemberantasan Tindak Pidana Korupsi dan Pasal 55 ayat (1) ke-1 KUHP serta Pasal 64 ayat (1) KUHP, maka masing-masing akan dipertimbangkan tersendiri dan yang pertama-tama akan dipertimbangkan adalah Pasal 3 Undang-undang Nomor: 31 Tahun 1999 sebagaimana telah diubah dengan Undang-undang Nomor: 20 Tahun 2001 tentang Perubahan Atas Undang-undang Nomor 31 Tahun 1999 tentang Pemberantasan Tindak Pidana Korupsi yang rumusannya berbunyi "Setiap orang yang dengan tujuan menguntungkan diri sendiri atau orang lain atau suatu korporasi, menyalahgunakan kewenangan, kesempatan atau sarana yang ada padanya karena jabatan atau kedudukan yang dapat merugikan keuangan negara atau perekonomian negara, dipidana dengan pidana penjara seumur hidup atau pidana penjara paling singkat 1 (satu) tahun dan paling lama 20 (dua puluh) tahun dan atau denda paling sedikit Rp.50.00o.ooo,oo (lima puluh juta Rupiah) dan paling banyak Rp.1.00o.ooo.ooo,oo (satu milyar Rupiah)".

Menimbang, berdasarkan bunyi Pasal 3 Undang-undang Nomor: 31 Tahun 1999 tentang Pemberantasan Tindak Pidana Korupsi sebagaimana telah diubah dengan Undang-undang Nomor 20 Tahun 2001 tentang Perubahan Atas Undang-Undang Nomor 31 Tahun 1999 tentang Pemberantasan Tindak Pidana Korupsi tersebut, bagian inti deliknya (bestanddeel delict) atau unsur-unsur tindak pidananya adalah sebagai berikut:

1. Yang dengan tujuan menguntungkan diri sendiri, orang lain atau suatu korporasi;

2. Menyalahgunakan kewenangan, kesempatan atau saran yang ada padanya karena jabatan atau kedudukan;

3. Yang dapat merugikan keuangan negara atau perekonomian negara;

Menimbang, terhadap unsur-unsur tersebut Majelis Hakim mempertimbangkan sebagai berikut: 
Ad. 1 Unsur Yang dengan tujuan menguntungkan diri sendiri, orang lain atau suatu korporasi;

Menimbang, kata "dengan tujuan" dalam unsur ini, tidak dimaksudkan bahwa Terdakwa benar-benar mengetahui dari awal bahwa perbuatan yang dilakukan disadari akan memberikan suatu keuntungan pada dirinya sendiri atau orang lain atau suatu korporasi sebagai suatu tujuan dari awal. Yang menjadi persoalan pokok dalam unsur ini adalah, apakah perbuatan Terdakwa memperoleh keuntungan untuk diri sendiri atau orang lain atau suatu korporasi dilakukan dengan cara menyalahgunakan kewenangan, kesempatan atau sarana yang ada padanya karena jabatanatau kedudukan tersebut atau tidak;

Menimbang, unsur ini bersifat alternatif dimaksudkan yang diuntungkan dari perbuatan Terdakwa dapat untuk diri sendiri atau orang lain atau suatu korporasi, dengan demikian jika salah satu diantaranya memperoleh keuntungan karena perbuatan terdakwa, maka unsur ini telah terpenuhi;

Menimbang, mengenai unsur ini, Penuntut Umum dalam tuntutan pidana pada halaman 43-46 berpendapat telah terpenuhi dan telah terbukti secara sah dan meyakinkan menurut hukum, sedangkan Penasihat Hukum terdakwa dalam Pembelaannya halaman 40-41 berpendapat unsur tidak

terbukti karena sepanjang pemeriksaan persidangan tidak diperoleh satupun fakta baik berupa alat bukti surat maupun keterangan saksi-saksi yang yang diajukan oleh penuntut umum yang saling bersesuaian.

Putusan hakim atas perara tersebut Menyatakan Terdakwa Mustagfir Sabry, S. Ag., M.Si tersebut diatas, tidak terbukti secara sah dan meyakinkan bersalah melakukan tindak pidana sebagaimana didakwakan dalam dakwaan primer dan subsider;

\section{Putusan Bebas Yang Diputuskan oleh Pengadilan Tindak Pidana Korupsi Terhadap Tindak Pidana Korupsi Putusan Nomor 89/Pid. Sus.Tpk/2018/PN. Mks dan Nomor 17/Pid.SUS.TPK/2015/PN. Mks}

Mengingat korupsi di Indonesia terjadi secara sistematik dan meluas sehingga tidak hanya merugikan keuangan Negara, tetapi juga telah melanggar hak-hak social dan ekonomi masyarakat secara luas, maka pemberantasan tindak pidana korupsi harus dilakukan dengan cara yang khusus, antara lain penerapan system pembuktian terbalik yakni pembuktian yang dibebankan kepada terdakwa.

Untuk mencapai kepastian hukum, menghilangkan keragaman penafsiran, dan perlakuan adil dalam pemberantas tindak pidana korupsi, perlu diadakan perubahan atas Undang-undang Nomor 31 tahun 1999 tentang Pemberantasan Tindak Pidana Korupsi. Ktetentuan ini diperluas mengenai sumber perolehan alat buktiyang sah yang berupa petunjuk, dirumuskan bahwa mengenai "petunjuk" selain diperoleh dari keterangan saksi, surat, keterangan terdakwa, juga diperoleh dari alat bukti lain yang berupa informasi yang diucapkan, dikirm, diterima, atau disimpan secara elektronik dengan alat optic atau yang serupa dengan itu tetapi tidak terbatas pada data penghubung elektronik, surat elektronikk, telegram, teleks, dan faksimili dan dari dokumen yakni setiap rekaman data atau informasi yang dapat dilihat, dibaca dan atau 
didengar yang dapat dikeluarkan dengan atau tanpa bantuan suatu sarana, baik yang tertuang diatas kertas, dll yang memiliki makna

Ketentuan mengenai "pembuktian terbalik" perlu ditambahkan dalam UU No. 31 Tahun 1999 tentang pemberantasan Tindak Pidana Korupsi sebegai ketentuan yang besifat "premium remidium" dan sekaligus mengandung sifat prevensi khusus terhadap pegawai negri sebagaimana dimaksud dalam Pasal 1 angka 2 atau terhadap penyelenggara Negara sebagaimana dimaksud dalam pasal 2 UU No. 28 Tahun 1999 tentang penyelenggara Negara yang bersih dan bebas dari korupsi, kolusi, nepotisme untuk tidak melakukan tindak pidana korupsi.

Pembuktian terbalik ini diberlakukan pada tindak pidana baru tentang gratifikasi dan terhadap tuntutan perampasan harta benda terdakwa yang diduga berasal dari salah satu tindak pidana sebagaimana dimaksud dalam pasal 2, pasal 3, pasal 4, pasal 13, pasal 14, pasal 15, dan pasal 16 UU No. 31 tahun 1999 tentang pemberantasan Tindak Pidana Korupsi dan pasal 5 sampai dengan pasal 12 UU ini.

Dalam Undang-undang ini diatur pula hak Negara untuk mengajukan gugatan perdata terhadap harta benda terpidana yang disembunyikan atau tersembunyi dan baru diketahui setelah putusan pengadilan memperoleh kekuatan hukum tetap. Harta benda yang berasal dari tindak pidana korupsi. Gugatan perdata dilakukan terhadap pidana dan ahli warisya. Untuk melakukan gugatan tersebut, Negara dapat menunjukan kuasanya untuk mewakili Negara.

Selanjutnya dalam undang-undang ini juga diatur ketentuan baru maksimum pidana penjara dan pidana denda bagi tindak pidana korupsu\i sebesar Rp 5.000.000,oo (lima juta rupiah). Ketentuan ini dimaksudkan untuk menghasilkan rasa kekurangadilan bagi pelaku tindak pidana korupsi dalam hal nilai yang di korup relative kecil.

Dengan demikian, jika diperhatikan dikaji secara seksama dengan memperlihatkan konsideran dan penjelasan umum bahwa dengan mengingat korupsi di Indonesia terjadi secara sistematik dan meluas sehingga tidak hanya dapat merugikan keuangan Negara, tetapi juga telah melanggar hak-hak social ekonomi masyarakat secara luas, maka pemberantasan korupsi perlu dilakukan dengan cara luar biasa. Cara luar biasa dimaksud selain penerapan system pembuktian terbaluk, peluasan mengenai sumber perolehan alat bukti yang sah terhadap harta benda terpidana, pidana denda yang lebih tinggi, dan penjara bagi pelaku tindak pidana korupsi yang tidak dapat membayar pidana tambahan berupa uang pengganti kerugian Negara, serta ditetapkannya ancaman pidana minimum khusus.

Berdasarkan uraian diatas, menurut hemat penulis setelah dianalisis proses penyelesaian perkara Tindak Pidana Korupsi hingga penjatuhan Hukuman baik bebas maupun tidak bebas Majelis Hakim sudah maksimal mempertimbangkan sesuai dengan bukti-bukti yang diajukan dan keterangan saksi-saksi serta keterangan ahli. Sehingga dengan demikian pertimbangan Hakim dalam melakukan putusan bebas terhadap Tindak Pidana Korupsi di Pengadilan Tindak Pidana Korupsi Makassar Nomor. 89/Pid.Sus.Tpk/2018/PN. Makassar dan Nomor 17/Pid.SUS.TPK/2015/PN. Makassar. 


\section{KESIMPULAN}

Pertimbangan Hukum Majelis dalam melakukan penilaian sah atau tidaknya alat bukti dalam penjatuhan Putusan bebas (vrijpraak) atau tidak bebas dalam perkara tindak pidana korupsi sangat tergantung pada validitas atau akurasi suatu alat yang diajukan, baik oleh terdakwa maupun Jaksa Penuntut Umum. Termasuk akurasi secara formal perolehan dari alat bukti tersebut sebagaimana penegasan peraturan perundang-undangan. Hal seperti ini dapat ditemukan dalam putusan kasasi Mahkamah Agung. Putusan bebas yang dijatuhkan atau diputuskan oleh Majelis Hakim dalam perkara Tindak Pidana Korupsi sudah sesuai dengan hukum pidana materil dan hukum pidana formil.

\section{SARAN}

1. Dalam hasil penelitian ini direkomendasikan bahwa dalam proses penangan tindak pidana korupsi baik oleh Jaksa Penuntut Umum maupun Kuasa Hukum agar dalam mengajukan alat bukti kiranya syarat formil dan syarat materilnya diperhatikan kesesuaiannya dengan syarat formil menurut peraturan perundang-undangan yang berlaku.

2. Mengingat korupsi Indonesia terjadi secara sistematik dan meluas sehingga tidak hanya merugikan Negara, tetapi jugta telah melanggar hak-hak social dan ekonomi masyarakat secara luas, maka pemberantasan korupsi dilakukan dengan cara yang luar biasa yaitu seperti pembuktian terbalik dan dengan ancaman yang seberat-beratnya.

\section{DAFTAR PUSTAKA}

Butarbutar, E. N. (2011). Asas Praduga Tidak Bersalah: Penerapan Dan Pengaturannya Dalam Hukum Acara Perdata. Jurnal Dinamika Hukum, 11(3), 470-479.

Dahlan, D. (2015). Distorsi Beban Pembuktian dalam Tindak Pidana Korupsi Menurut Sistem Pembuktian. Jurnal Hukum Samudra Keadilan, 10(1), 68-77.

Gerungan, L. K. (2011). Dimensi Dan Implementasi "Perbuatan Melawan Hukum Materiil" Dalam Tindak Pidana Korupsi Pada Putusan Mahkamah Agung Pasca Putusan Mahkamah Konstitusi. Jurnal Hukum Unsrat, 19(5), 60-74.

Gunarto, M. P. (2012). Asas Keseimbangan Dalam Konsep Rancangan Undang-Undang Kitab Undang-Undang Hukum Pidana. Mimbar Hukum-Fakultas Hukum Universitas Gadjah Mada, 24(1), 83-97.

Ipakit, R. (2015). Urgensi Pembuktian Alat Bukti Dalam Praktek Peradilan Pidana. Lex Crimen, 4(2).

Mas, M. (2012). Penguatan Argumentasi Fakta-Fakta Persidangan dan Teori Hukum Dalam Putusan Hakim. Jurnal Yudisial, 5(3), 283-297.

Mulyadi, L. (2015). Asas Pembalikan Beban Pembuktian terhadap Tindak Pidana Korupsi dalam Sistem Hukum Pidana Indonesia Dihubungkan dengan Konvensi 
Perserikatan Bangsa-Bangsa Anti Korupsi 2003. Jurnal Hukum dan Peradilan, 4(1), 101-132.

Rahman, S., \& Qamar, N. (2014). Etika Profesi Hukum. Pustaka Refleksi, Makassar.

Rasul, S. (2009). Penerapan Good governance di Indonesia dalam upaya pencegahan tindak pidana korupsi. Mimbar Hukum-Fakultas Hukum Universitas Gadjah Mada, 21(3), 538-553.

Sriwati, S. (2018). Putusan Bebas (Vrijspraak) Dalam Kasus Korupsi. Jurnal Yustika: Media Hukum dan Keadilan, 14(1), 52-66.

Suhendar, S. (2019). Penyidikan Tindak Pidana Korupsi Dan Kerugian Keuangan Negara Dalam Optik Hukum Pidana. Pamulang Law Review, 1(1), 85-100.

Thalib, H., Ramadhan, A., \& Djanggih, H. (2017). The Corruption Investigation In The Regional Police of Riau Islands, Indonesia. Rechtsidee, 4(1), 71-86.

Wiriadinata, W. (2016). Korupsi dan Pembalikan Beban Pembuktian. Jurnal Konstitusi, 9(2), 313-332. 